\title{
The potentiation effect of Bawang Dayak (Sisyrinchium palmifolium L.) extract on T47D cell growth inhibition after 5-fluorouracil treatment
}

\author{
Azizah Yuniarti, Elza Sundhani, Nunuk Aries Nurulita* \\ Faculty of Pharmacy Universitas Muhammadiyah Purwokerto \\ Jl. Raya Dukuhwaluh Kembaran Purwokerto, Central Java, Indonesia
}

Submitted: 03- 04- 2018

Reviewed: 05-05-2018

Accepted: 02-11-2018

\begin{abstract}
5-Fluorouracil (5-FU) is chemotherapeutic agents used in breast cancer treatment. However 5FU has low effectiveness as chemotherapeutic agent after longterm used. 5-FU usually combined with other compounds to increase its effectivity. Bawang Dayak has been widely used empirically as a cancer treatment, especially breast cancer. The aim of this study was to determine the sensitivity of 5FU as cytotoxic agent against T47D breast cancer cells and their combination with extract of Bawang Dayak (EBD), to determine apoptotic induction mechanism, and the inhibitory effect of T47D breast cancer cell cycle. The cytotoxicity properties were determined using the MTT method with the concetration series of 5-FU $(0-600 \mu \mathrm{g} / \mathrm{mL})$ and EBD $(0-250 \mu \mathrm{g} / \mathrm{mL})$. The combination between 5-FU $(2-250 \mu \mathrm{g} / \mathrm{mL}$ and EBD $(5-50 \mu \mathrm{g} / \mathrm{mL})$ was used for combination treatment on T47D cells. The apoptotic cells after treatment were determined by propidium iodide/annexin $\mathrm{V}$ reagent using flowcytometry. The modulation effect of combination treatment between 5-FU and EBD was performed by determination of DNA content using flowcytometry. The treatment of 5-FU and EBD inhibited T47D cell growth with $\mathrm{IC}_{50}$ value $274 \mu \mathrm{g} / \mathrm{mL}$ and $75 \mu \mathrm{g} / \mathrm{mL}$, respectively. The combination therapy of 5-FU and EBD resulted a mild to strong synergistic effect, with combination index (CI) 0.829 and 0.779 . The combined treatment $(125 \mu \mathrm{g} / \mathrm{mL} 5-\mathrm{FU}$ and $25 \mu \mathrm{g} / \mathrm{mL}$ EBD) induced apoptosis in T47D cells by $21.33 \%$. This combination caused $57.11 \%$ cell accumulation in $\mathrm{G}_{0}-\mathrm{G}_{1}$ phase, that greater than control grup (41.20\%). The combination treatment (5-FU and EBD) cause cell distubance and damage that lead to $\mathrm{G}_{0^{-}}-\mathrm{G}_{1}$ phase cell cycle arrest. The cell cycle can not proceed to the next phase. EBD produce synergistic effect when used as breast cancer co-chemotherapy with 5-FU. It was particularly able to induce apoptosis against T47D cells followed by $\mathrm{G}_{0}-\mathrm{G}_{1}$ phase accumulation. The extract of Bawang Dayak has a high potential to be developed as co-chemotherapy in breast cancer.
\end{abstract}

Keywords: Bawang Dayak, 5-fluorouracil, T47D, co-chemotherapy, apoptosis, cell cycle

\footnotetext{
*Corresponding Author:

Nunuk Aries Nurulita

Faculty of Pharmacy, Universitas Muhammadiyah Purwokerto

Jl. Raya Dukuhwaluh Kembaran, Purwokerto

Email: nunuknurulita0@gmail.com
} 


\section{INTRODUCTION}

Cancer is the second most prevalent disease in the world after heart and blood vessel diseases. International Agency for Research on Cancer (IARC) in 2012 reports the breast cancer in the world reaches second ranked after lung cancer on incidency and mortality, which is $43.1 \%$ and $17.9 \%$, respectively. The incidence and death rates from breast cancer in Indonesia were 48,998 and 19,750 (Ministry of Health Republic of Indonesia, 2014). The high prevalence of cancer in Indonesia requires greater attention to find out the solution of the obstacle of breast cancer therapy.

One of the breast cancer chemotherapy is 5-fluorouracil (5-FU). 5-FU has adverse and toxic effects such as diarrhea and myelotoxicity (National Comprehensive Cancer Network, 2014). The effectiveness of 5-FU as a chemotherapeutic agent is only $15 \%$, so it need to combined with other compounds to improve its effectiveness of therapy (Meyerhardt and Mayer, 2005). The combination is expected produced a additive to synergistic effect. The compounds that extracted and isolated from medicinal plants that have been empirically used as cancer chemoprevention and co-chemotherapy for increasing the potency of chemotherapy agents that already establish as cancer chemotherapeutic agent.

Bawang Dayak (Sisyrinchium palmifolium L.) is a typical plant of Central Kalimantan that has been empirically used for the treatment of hypertension, diabetes, hyperlipidemia, stroke, and cancer, and particularly breast cancer (Galingging, 2009). Bawang Dayak bulbs contain flavonoid compounds, polyphenols, monoterpenes, sesquiterpenes, and steroids. Bawang Dayak ethanolic extract has strong antioxidant activity with $\mathrm{IC}_{50}$ value of $46.14 \mathrm{ppm}$ (Hidayah et al., 2015). The ethanolic extract of Bawang Dayak has cytotoxic effect on HT29 colon cell carcinoma with $\mathrm{IC}_{50}$ of $3.125 \mathrm{ppm}$, while $\mathrm{IC}_{50}$ of 5-FU was 150 ppm (Yusni, 2008). Sudarmawan (2009) reported Bawang Dayak ethanolic extract has activity against breast cancer cell T47D with $\mathrm{IC}_{50}$ value of $125 \mathrm{ppm}$. Thus Bawang Dayak ethanolic extract may contain potent active compounds to be developed as anti-cancer.

In this research, ethanolic extract of Bawang Dayak is combined with 5-FU used to treat T47D breast cancer cell. The study was conducted by comparing the cytotoxicity effects of 5-FU and Bawang Dayak ethanolic extract as a single treatment as well as a combination of both, observing proliferative inhibition, and T47D breast cancer cell apoptosis. The combination of 5-FU and Bawang Dayak ethanolic extract has been shown to increase the effectiveness of 5-FU therapy in T47D breast cancer.

\section{MATERIALS AND METHODS Materials}

Bawang Dayak bulbs are obtained from Samarinda, East Kalimantan. Plant identification was done at the Laboratory of Plant Taxonomy, Faculty of Biology, University of Jenderal Soedirman, 70\% ethanol, 5-FU, T47D cells (Parasitology Laboratory, Faculty of Medicine, Gadjah Mada University). DMEM (Sigma Aldrich)-containing media Fetal Bovine Serum (FBS) (Gibco) $10 \%$ (v/v) and 2\% (v / v) penicillin-streptomycin antibiotics (Sigma Aldrich), dimethyl sulfoxide (DMSO) (Sigma Aldrich), 3-(4,5 dimethyltoyo-2-yl) 2,5-diphenyltetrazolium bromide (MTT) (Sigma Aldrich) $5 \mathrm{mg} / \mathrm{ml}$, Annexin V (Merck), and propidium iodide (Merck).

\section{Methods}

\section{Extract Preparation}

Bawang Dayak bulbs were washed with clean water, then dried and grounded with a grinder and then put into a sealed plastic bag (MOH, 2000 ). A total of 100 grams of Bawang Dayak bulb powders were macerated with 1 liter of ethanol $70 \%$ for 3 days, the comparison between simplicia and solvent was 1:10. After 3 days, then filtered the filtrate and thickened using a rotary vaccum evaporator until the viscosity was slightly viscous. This process was continued by evaporated on a waterbath with a temperature of $60^{\circ} \mathrm{C}$ to obtain ethanol condensed extract. The extract is placed at $4^{\circ} \mathrm{C}$ prior to used. 


\section{The cytotoxicity assay of single and combination using MTT}

The T47D cells with a density of $10^{4}$ cells/well were distributed into 96 well plates and incubated for 24 hours. Cells were treated with ethanolic extract of Bawang Dayak (EBD) $(25,50$, $100,175,250,500$, and $1000 \mu \mathrm{g} / \mathrm{mL})$ or 5 -FU $(200,300,400,500$, and $600,700,800 \mu \mathrm{g} / \mathrm{mL})$ for a single test. While for the combination test used $\operatorname{EBD}(5,10,25$, and $50 \mu \mathrm{g} / \mathrm{mL})$ and $5-\mathrm{FU}(25,50,125$, and $250 \mu \mathrm{g} / \mathrm{mL}$ ), then incubated for 24 hours. At the end of the incubation, the culture medium was removed, and washed with FBS. Then we added $100 \mu \mathrm{l}$ MTT $0.5 \mathrm{mg} / \mathrm{mL}$ into each well and incubated again for 4 hours at $37^{\circ} \mathrm{C}$. After incubation we added $100 \mu \mathrm{SDS} 10 \%$ in $0.1 \mathrm{~N} \mathrm{HCl}$ solution. Cells were incubated overnight at room temperature and shielded from light, then read with ELISA reader at $\lambda 595 \mathrm{~nm}$ (CCRC, 2013).

\section{Apoptotic assay using PI/Annexin V}

The T47D Cells with a density of $4 \times 10^{5}$ cells/well were distributed into 6 well plate and incubated for 24 hours. At the end of the cell incubation was washed with FBS $500 \mu \mathrm{L}$. Cells were given single treatment of EBD $(25 \mu \mathrm{g} / \mathrm{mL})$, single 5-FU (50 and $125 \mu \mathrm{g} / \mathrm{mL})$, and a combination of both agents. The combination treatment used at this study are EBD $25 \mu \mathrm{g} / \mathrm{mL}-5$-FU $50 \mu \mathrm{g} / \mathrm{mL}$ and EBD $25 \mu \mathrm{g} / \mathrm{mL}-5$-FU $125 \mu \mathrm{g} / \mathrm{mL}$. Then reincubated in $\mathrm{CO}_{2}$ incubator for 24 hours. At the end of the incubation time, the cell condition is documented. Cells were harvested using $0.25 \%$ trypsinEDTA and added subsequently added $400 \mu \mathrm{L}$ PI/Annexin-V-Fluos-labeling solution in each microtube then homogenized carefully using vortex. Each microtube is wrapped with aluminum foil and marked on the top of microtube. All was incubated in waterbath $37^{\circ} \mathrm{C}$ for 10 minutes to activate RNAse. Cell suspension is transferred into flowcyto-tube through filter (nylon fabric or glass cloth) then analysed using flowcytometer (CCRC, 2013 ${ }_{\mathrm{a}}$ ).

\section{Cell cycle assay using Flowcytometry}

Cells with a density of $4 \times 10^{5}$ cells/well $\left(4 \times 10^{5}\right.$ cells $/ 1000 \mu \mathrm{L}$ culture medium) were distributed into 6 wells plate and then incubated for 24 hours. Cells were treated with EBD $(25 \mu \mathrm{g} / \mathrm{mL})$ and 5-FU $(125 \mu \mathrm{g} \mathrm{mL})$ and as control cells were given $1000 \mu \mathrm{L}$ culture medium. Then reincubated in $\mathrm{CO}_{2}$ incubator for 24 hours. At the end of the incubation time, the cell morphological condition was documented. The harvested cells were then fixed with ethanol $70 \%,-20^{\circ} \mathrm{C}$ and washed with PBS. Cells were added with $400 \mu \mathrm{L}$ flowcytometry reagents in each microtube, resuspended until homogen. Each microtube is wrapped with aluminum foil and marked on the top of eppendorf. All microtube was incubated in waterbath $37^{\circ} \mathrm{C}$ for 10 minutes to activate RNAse. The cell suspension is transferred into flowcyto-tube through filter (nylon fabric or glass cloth) the analysed using flowcytometer to determine cell cycle profile. The data was analyzed by a cell quest program to observe the distribution of cells in each phase of cell cycle. Flowcytometry is performed with a light emission of $488 \mathrm{~nm}$ and with a medium speed of 500 cells/second (CCRC, $2013_{\mathrm{b}}$ ).

\section{Data Analysis}

\section{The cytotoxicity assay for single compound}

The data obtained as absorbance of each well used to calculate cell viability (live cell percentage). The formula is:

$$
\% \text { viable }=\frac{\text { Sample Absorbance }- \text { Medium Control Absorbance }}{\text { Cell Control Absorbance }- \text { Medium Control Absorbance }} \times 100 \%
$$

$\mathrm{IC}_{50}$ (Inhibitory Concentration 50\%) is determined by the logarithmic equation between the absorbance value and the concentration of the extract.

\section{The cytotoxicity assay for combination treatment}

The effect of the combination between EBD and 5-FU were analysed using the combination Index (CI) value with the equation (Reynold and Maurer, 2005): 
$\mathrm{CI}=(\mathrm{D})_{1} /\left(\mathrm{D}_{\mathrm{X}}\right)_{1}+(\mathrm{D})_{2} /\left(\mathrm{D}_{\mathrm{X}}\right)_{2}$

Description:

$\mathrm{D}_{\mathrm{X}}$, the concentration of a single compound is required to give effect as much as the combined one, D1 and D2, the concentration of the two compounds (1 and 2) is used as combination treatment.

Table I . Interpretation of CI value (Reynold and Maurer, 2005)

\begin{tabular}{cl}
\hline CI Values & \multicolumn{1}{c}{ Interpretation } \\
\hline$<0.1$ & Very strong synergism \\
$0.1-0.3$ & Strong sinergism \\
$0.3-0.7$ & Synergism \\
$0.7-0.9$ & Mild to moderate synergism \\
$0.9-1.1$ & Additive \\
$1.1-1.45$ & Mild to moderate antagonism \\
$1.45-3.3$ & Antagonism st very strong \\
$>3.3$ & Strong to antagonism \\
& a \\
\hline
\end{tabular}

\section{Result and Dicussions}

The EBD and 5-FU treatment resulted morphologically changing on T47D cells. Most of cell population was detached from tissue culture dish than become floating in culture medium. Most of detached cells became spherical shape and generated apoptotic bodies (Figure 1).
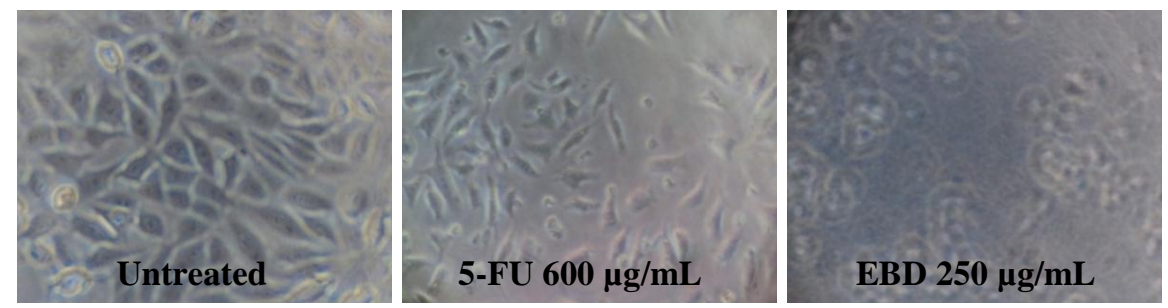

Figure 1. The effect of 5-FU $(600 \mu \mathrm{g} / \mathrm{mL})$ and EBD $(250 \mu \mathrm{g} / \mathrm{mL})$ treatment against T47D cancer cells with a density of $10^{4}$ cells distributed on 96 wells, 24-hour incubation. Observations under an inverted microscope showed that there was a difference in cell morphology after treatment

The effect of EBD on T47D cells viability are shown by a sigmoid curve as relation between EBD concentration versus viable cell (\%). The treatment of EBD resulted inhibition of T47D cell viability with dose dependent manner while 5-FU resulted similar effect after various concentration treatment (Figure 2).
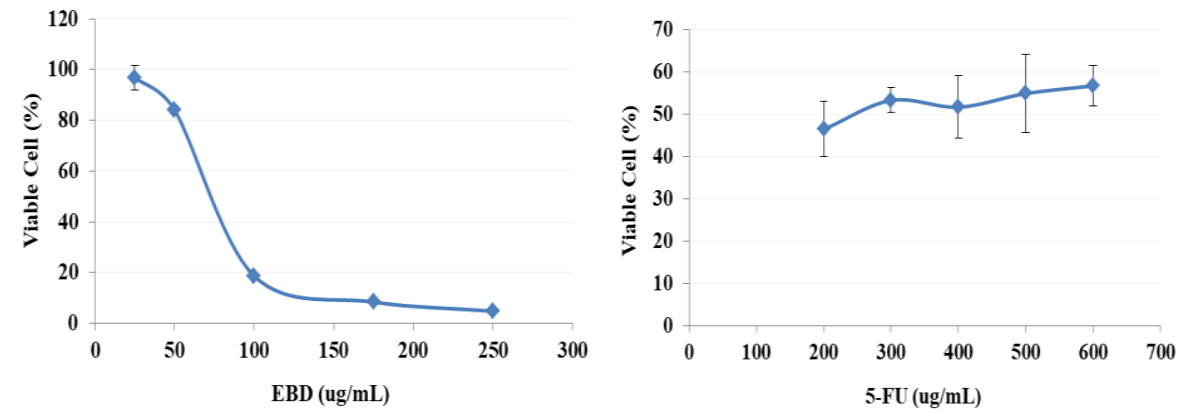
Figure 2. The effect of combination of EBD and 5-FU treatment on cell viability

The sensitivity of T47D cells against EBD was determined by the $\mathrm{IC}_{50}$ value. EBD inhibited T47D cells growth after 24 hours incubation, with $\mathrm{IC}_{50}$ value $76 \mu \mathrm{g} / \mathrm{mL}$. Bawang Dayak consisted several compounds affected the inhibition of T47D breast cancer cells viability. Bawang Dayak contain anthraquinone compound and one was determined as naphthoquinone. This active compound was suspected to be naphthoquinone that already known as an anticancer and antioxidant. This compound was usually present in vacuoles in the form of glycosides (Babula et al., 2009; Babula et al., 2005).

5-FU resulted on T47D cell growth inhibition with $\mathrm{The} \mathrm{IC}_{50}$ value $274 \mu \mathrm{g} / \mathrm{mL}$ that higher if compared with the previous research $(2.97 \mu \mathrm{g} / \mathrm{mL})$ (Sukardiman et al., 2014). The presence of hydroxyl and fluoro groups in 5-FU thought to contribute to its toxicity properties (Folmer et al., 2006 and Kim, 2006). 5-FU is an antimetabolite that acts antagonistically with thymine against thimidylatesintase (TS) enzyme activity. 5-FU produces fluoridin-5-triphosphate (FUTP) that combines into RNA and affects its function and fluorodeoxyuridate (FdUMP) that inhibits DNA replication (Longley and Johnston, 2007).

The EBD and 5-FU treatments showed morphologicaly changes in T47D cells compared with controls (Figure 1). The EBD $(250 \mu \mathrm{g} / \mathrm{mL})$ treatment resulted more severe of T47D cell dead. The treatment of 5-FU $(600 \mu \mathrm{g} / \mathrm{mL})$ caused decreasing of T47D cell size. The changing of cell morphology may lead the decreasing of viability of T47D cells.

The combination treatment of EBD and 5-FU might be increased the sensitivity of 5-FU chemotherapy agents against T47D breast cancer cells. It needs further determination of the combination treatment on combination cytotoxicity, apoptosis induction, and cell cycle inhibition assay.

\section{The potency of cytotoxicity effect of 5-FU dan EBD combination}

The cytotoxicity assays of 5-FU and EBD combination were performed using several concentrations below $\mathrm{IC}_{50}$ of $\operatorname{EBD}(5,10,25$, and $50 \mu \mathrm{g} / \mathrm{mL})$ and 5-FU $(25,50,125$, and $250 \mu \mathrm{g} / \mathrm{mL})$. The combinations treatment decreased T47D cell viability, higher than the treatment of single one. The lowest of T47D cell viability was obtained after treated by combination of 5-FU-EBD $(125 \mu \mathrm{g} / \mathrm{mL}-50$ $\mu \mathrm{g} / \mathrm{mL}$ (Figure 3).
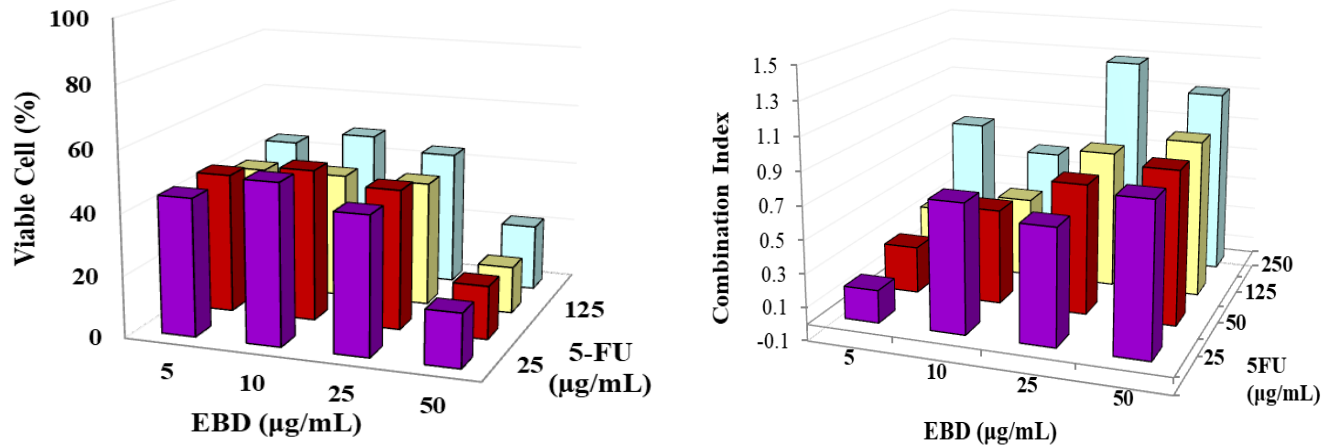

Figure 3. The CI values of EBD and 5-FU on various concentration variations in T47D cells

The combination treatment resulted mild-moderate antagonists to strong synergis effect. The combination of 5-FU and EBD $(125-5 ; 50-10 ; 125-10 ; 250-10 ; 25-25 \mu \mathrm{g} / \mathrm{mL})$ resulted synergistic effect with the CI values above 0.3. From these results proved that EBD has the potential to be used as a 5-FU co-chemotherapy agent. Giving a combination of 5-FU and EBD at that concentrations provides a synergistic effect until very strong synergist against T47D breast cancer cells. 


\section{The cell death induction of T47D cell after 5-FU and EBD treatment}

The apoptotic induction result various changes in the plasma membrane including changes in permeability and lipid membrane. During apoptosis major changes occur in lipid membranes where phosphatidilserin (PS) is translocated from the inner to outer membrane. Phosphatidilserine (PS) binds to Annexin $\mathrm{V}$ and this change can be observed by cell incubation with Annexin V. In normal living cells, phosphatidylserine (PS) lies on the cytoplasmic surface of the membrane cell. During apoptotic induction, rapid changes occur in phospholipids in cells that cause changes in PS positions on the cell surface. The bonding ability between Annexin V and PS occurs very quickly with the presence of $\mathrm{Ca}^{2+}$ ions. PS translocation on the cell surface precedes nuclear changes and DNA fragmentation. These changing will lead to apoptotic cell death. The appearance of Annexin V and PS bonding could be used as a marker of early apoptosis (Ormerod, 2000).

The apoptosis assay by flowcytometry measures the percentage of cell death by apoptosis and necrosis, as well as the number of cells that remain normally alive. The single treatment both of 5-FU and EBD induced the increasing of of cell death on T47D cells. The cell death mechanism suspected trough apoptosis mechanism. The combinations treatment of 5-FU and EBD that used at this experiment are $50-25$ and $125-25 \mu \mathrm{g} / \mathrm{mL}$ as the best combination that provide mild to moderate synergistic effect on T47D cells growth inhibition (Figure 4).
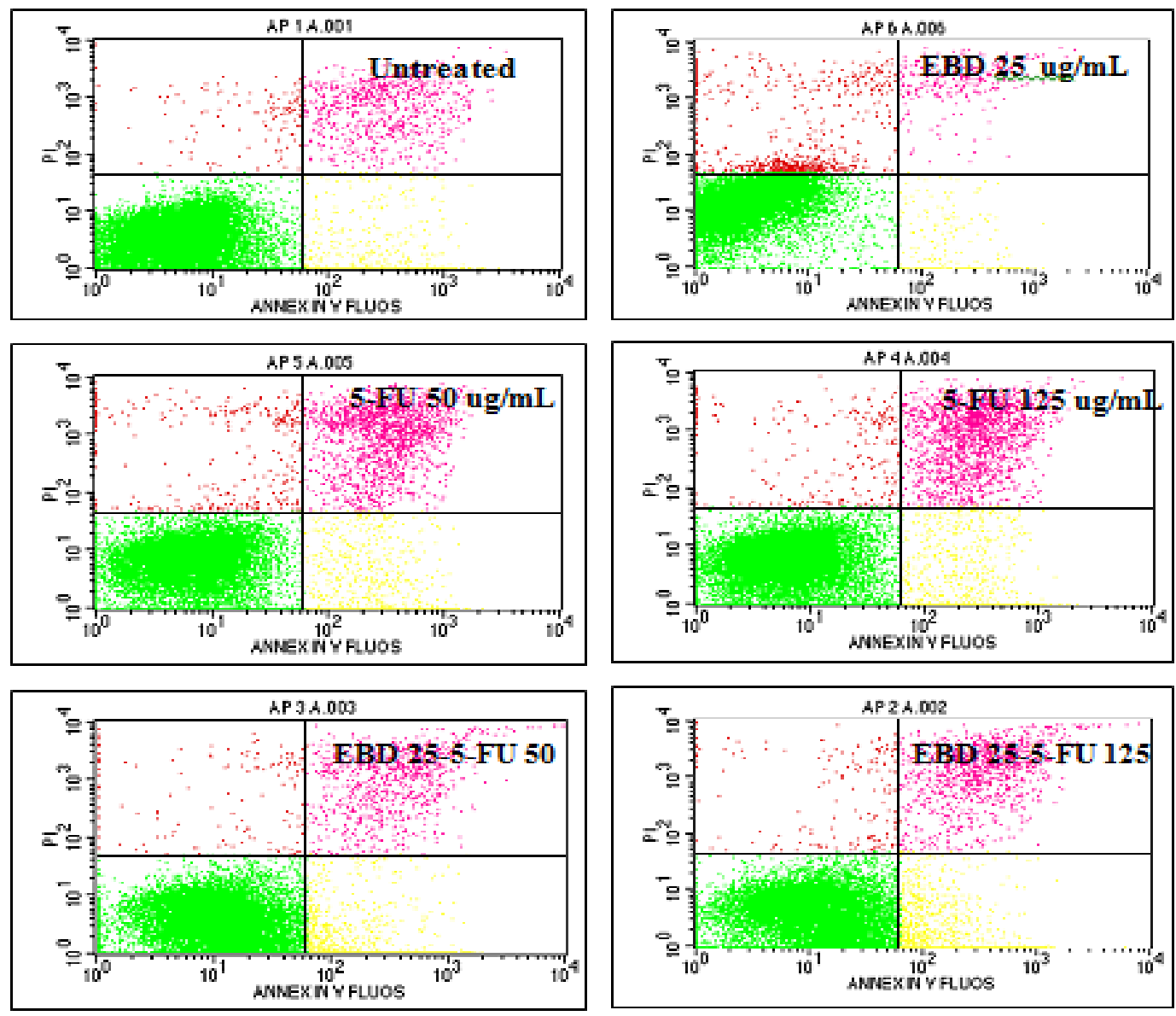

Figure 4. The apoptosis induction effect after treated by 5-FU, EBD as single and combination treatment. The lower right (LR) quandrane indicates a living cell, lower left (LL) showing cells undergoing early apoptosis, upper left (UL) is showing a late apoptotic cell, and upper right (UR) is showing necrotizing cells 
Table II. The effect of 5-FU and EBD as single and combination treatment on percentage of apoptotic and necrotic cells

\begin{tabular}{|c|c|c|c|c|c|}
\hline Treatment & $\begin{array}{c}\text { Concentration } \\
(\mu \mathrm{g} / \mathrm{mL})\end{array}$ & $\begin{array}{c}\text { Viable cells } \\
\text { (LR) } \\
(\%)\end{array}$ & $\begin{array}{c}\text { Early } \\
\text { apoptotic } \\
\text { cells (LL) } \\
(\%)\end{array}$ & $\begin{array}{c}\text { Late } \\
\text { apoptotic cells } \\
(\mathbf{U L}) \\
(\%)\end{array}$ & $\begin{array}{l}\text { Necrotic cells } \\
\text { (UR) } \\
(\%)\end{array}$ \\
\hline $\begin{array}{l}\text { Untreated } \\
\text { cell }\end{array}$ & - & $91.28 \pm 0.08$ & $4.35 \pm 0.01$ & $3.64 \pm 0.21$ & $0.65 \pm 0.01$ \\
\hline EBD & 25 & $93.27 \pm 0.68$ & $1.52 \pm 0.00$ & $1.36 \pm 0.01$ & $4.39 \pm 0.62$ \\
\hline 5-FU & 50 & $79.73 \pm 0.12$ & $10.10 \pm 0.02$ & $8.48 \pm 0.05$ & $1.72 \pm 0.07$ \\
\hline 5-FU & 125 & $78.97 \pm 0.14$ & $10.37 \pm 0.00$ & $9.38 \pm 0.09$ & $1.31 \pm 0.03$ \\
\hline 5-FU-EBD & $50-25$ & $80.40 \pm 0.23$ & $14.61 \pm 0.10$ & $4.30 \pm 0.06$ & $0.73 \pm 0.04$ \\
\hline 5-FU-EBD & $125-25$ & $77.74 \pm 0.35$ & $16.05 \pm 0.17$ & $5.45 \pm 0.06$ & $0.85 \pm 0.02$ \\
\hline
\end{tabular}

The results of apoptotic observation using flowcytometer showed that EBD treatment at 25 $\mu \mathrm{g} / \mathrm{mL}$ concentration with 24 hours incubation time caused $2.88 \%$ of cells undergo apoptosis (an accumulation of $1.52 \%$ early apoptosis and $1.36 \%$ late apotosis), lower than untreated cells $(7.99 \%$, as an accumulation $4.35 \%$ early apoptosis and $3.64 \%$ late apoptosis). 5 -FU treatment $(50 \mu \mathrm{g} / \mathrm{mL}$ and 125 $\mu \mathrm{g} / \mathrm{mL}$ ) after 24-hour incubation period resulted in $18.58 \%$ and $19.75 \%$ of cells apoptosis (as an accumulation of early and late apoptosis cells), respectively (Table III). The combination treatment elevated the persentage of apoptotic cells and particularly decreased the persentage of necrotic cells compared with single treatment either of 5-FU or EBD. These data suggest that EBD treatment can improve the ability of 5-FU in spurring the occurrence of apoptosis in T47D cells. The incresing number of apoptotic cell causes the decreasing of T47D cell viability. The cytotoxic effects also causes the cell cycle arrest.

\section{T47D cell cycle inhibition due to single and combinations treatment of 5-FU and EBD}

The accumulation of cells in the cell cycle is one of the main targets of anticancer agents. The largest cell accumulation in the 5-FU-EBD combination treatment at $125 \mu \mathrm{g} / \mathrm{mL}-25 \mu \mathrm{g} / \mathrm{mL}$ concentration was in the G0-G1 phase of $57.11 \%$. The combination of 5-FU125 $\mu \mathrm{g} / \mathrm{mL}-\mathrm{EBD} 25$ $\mu \mathrm{g} / \mathrm{mL}$ resulted G0-G1 phase arrest higher than untreated cells (Figure 5 and Table III).
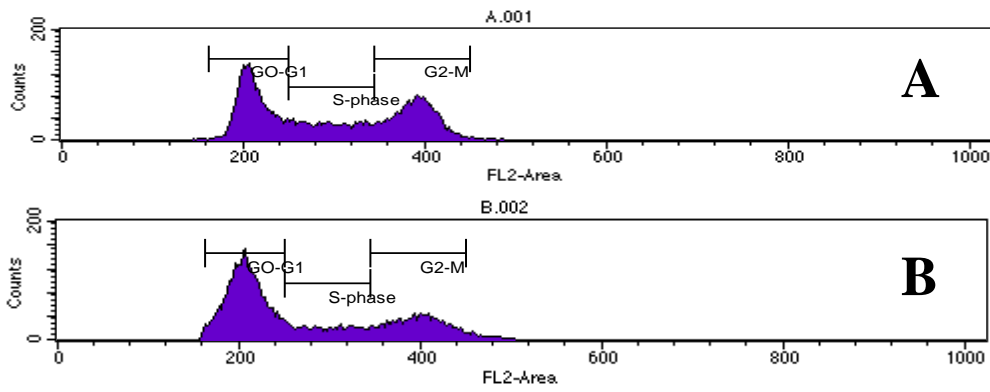

Figure 5. The T47D cell cycle profile without treatment (A) and after combination treatment $(125-25 \mu \mathrm{g} / \mathrm{mL})(B)$ 
Table III. The distribution of T47D cells after treatment with a combination of 5FU and EBD

\begin{tabular}{lllll}
\hline \multicolumn{1}{c}{ Treatment } & \multicolumn{1}{c}{ Concentration } & \multicolumn{3}{c}{ Phase (\%) } \\
& \multicolumn{1}{c}{ G0-G1 } & S-Phase & G2-M \\
\hline Untreated cell & - & 41.20 & 22.60 & 36.28 \\
5-FU-EBD & $\begin{array}{l}125 \mu \mathrm{g} / \mathrm{mL}-25 \\
\mu \mathrm{g} / \mathrm{mL}\end{array}$ & 57.11 & 15.79 & 25.39 \\
& & & & \\
\hline
\end{tabular}

At the previous experiment, Hidayah, et al., (2015) reported Bawang Dayak bulbs contain terpenoid group compounds. Ircinin is one of the terpenoid compounds reported to cause G1 arrest in skin cancer cells (Mayer and Gustafson, 2003). The natural sequiterpenoids particularly induce G1 arrest on cell cycle progression through p21 and p27 induction. These proteins included in Cyclin Dependent Kinase inhibitors (CDKIs). Expression of p21 and p27 leads to a decrease in cyclin D levels so that no CDK4 and CDK6 activation occurs. Activation of CDK4 and CDK6 serves for the phosphorylation of Rb protein (retinoblastoma), so if there is blocking of CDK4 and CDK6 activation there is no phosphorylation of $\mathrm{Rb}$ protein. Unphosphorylated $\mathrm{Rb}$ will bind to the transcription factor E2F binding to DNA and inhibit the transcription of genes whose products are required for phase $\mathrm{S}$ cell cycle so that cells are retained in phase G0-G1 or G1 arrest (Kundu, 2012). The previous research by Guo et al. (2008) showed the largest cell accumulation in the 5-FU treatment of T47D cells occurred in G1 phase. 5-FU is an antimetabolite that acts antagonistically with thymine against the activity of thimidylate synthase (TS) enzyme. 5-Fluorouracil can not work on cells outside the cell (G0). 5-Fluorouracil only acts on cells that are active in the cell cycle where TS activity is required for the synthesis of the basic constituents of DNA. TS is expressed high in phase G1 via an intermediate transcriptional activity of E2F. The TS itself directly synthesizes the necessary dUMP precursors in the synthesis phase. Treatment with 5-FU in cancer cells can cause cell accumulation in G1 phase and early synthesis phase (G1 arrest).

The combination treatment of EBD and 5-FU was conducted to find out how the combination effect on T47D cell cycle. In combination treatment, the largest accumulation was in the G0-G1 phase of $57.11 \%$, in which phase G0-G1 protein synthesis spurred cell division which will form spindle cleavage. Provision of 5-FU and EBD combination treatments causes disturbance and damage to cells that cause cell breaks in G0-G1 phase and can not proceed to S phase.

\section{CONCLUSSION}

The combination treatment of 5-fluorouracil and Bawang Dayak ethanolic extract has a strong synergistic effect as breast cancer co-chemotherapy through apoptotic induction and cell accumulation in $\mathrm{G}_{0}-\mathrm{G}_{1}$ phase on breast cancer, T47D cells.

\section{REFERENCE}

Babula, P., Adam, V., Havel, L., Kizek ,R., 2009. Noteworthy secondary metabolites napthoquinones their occurrence, pharmacological properties and analysis. Curr Pharmaceut Anal 5 (1): 47-68.

Babula, P., Mikelova R., Potesil, D., Adam V., Kizek, R., Havel, L., Sladky, Z., 2005. Simultaneous determination of 1,4-naphtoquinone, lawsone, juglone and plumbagin by liquid chromatography with UV detection, Biomed Pape, 149: 25-28.

CCRC, 2013a. Sel T47D, Cancer Chemoprevention Research Center, Fakultas Farmasi Universitas Gadjah Mada. Yogyakarta.

CCRC, 2013 . Protocol, Cancer Chemoprevention Research Center Fakultas Farmasi Universitas Gadjah Mada. Yogyakarta.

Folmer, Y., Scheneider, M., Blum H.E., Hafkemeyer, P., 2007. Reversal of drug resistance of hepatocellular carcinoma cells by adenoviral delivery of anti ABCC2 antisense constructs, Cancer Gene Ther, 14:875-884. 
Galingging, R. Y., 2009. Bawang Dayak (Eleutherine palmifolia) sebagai tanaman obat multifungsi. Warta Penelitian dan Pengemangan, 15(3). 2-4.

Guo, X. Goessl., E. Jin., G. Colli-Duguid., ESR., Cassidy., J. Wang., W. and O’brien, V. 2008. Cell cycle perturbation and acquired 5-Fluorouracil chemoresistance, Anticanncer research, 28: 914.

Hidayah, A., S., Kiki, M., Leni, P., 2015. Uji aktivitas antioksidan umbi Bawang Dayak (Eleutherine bulbosa Merr.). Preceeding of Pharmacy, Seminar Penelitian Sivitas Akademika Unisba

International Agency for Research on Cancer (IARC), WHO. 2015. Breast Cancer Estimated Incidence, Mortality and Prevalence Worldwide in 2012.

Kim, Y.I., 2006. Does a high folate intake increase the risk of breast cancer? Nutr. Rev., 64 (10 Pt $1): 468-75$.

Kundu, TK., 2012. Epigenetics: Development and diseases, Springer.

Longley, DB., and Johnston, PG. 2005. Molecular mechanisms of drug resistance, Molecular and cellular themes in cancer research, 205(2):275-292.

Longley, D.B. dan Johnston P.G. 2007. 5-Fluorouracil Molecular Mechanism of Cell Death in Srivastava R., Apoptosis, Cell Signaling, and human Disease. Humana Press.

Mayer and Gustafson, 2003, Marine pharmacology in 2000: antitumor and cytotoxic compunds, International Journal of Cancer Banner, 105(3): 291-299.

Meyerhardt, J.A. and Mayer R.J. 2005. Systemic Teraphy for Colorectal Cancer. N. Engl. J. Med. 352(5). 476-487.

Ministry of Health, Republic of Indonesia, 2014. Indonesia Health Profile 2013, Jakarta.

National Comprehensive Cancer Network. 2014, Stage IV Breast Cancer. NCCN Guidelines for Patient.

Ormerod, MG., 2000. Flow Cytometry: A Practical Approach, Third Edition, Practical Approach Series, Oxford University Press.

Reynolds, C.P. and Maurer, B.J. Evaluating Response to Antineoplastic Drug Combinations in Tissue Culture Models. Methods in Molecular Medicine, 110:173-183.

Sudarmawan, I. H. 2009. Pengaruh pemberian fraksi etanolik dan petroleum eter ekstrak umbi Bawang Dayak (Eleutherine palmifolia (L.) Merr.) terhadap ekspresi p53 mutan galur sel kanker payudara T47D, Skripsi, Surakarta: Universitas Sebelas Maret.

Sukardiman, Herra S., Rahman A., Mulja H. S., Pratama, FA., 2014. Thylacetate Fraction Andrographis paniculata Nees Increases Cytotoxic Effect 5-Fluorouracil on Human Cancer Cell Lines, International Journal of Pharmacy and Pharmaceutical Sciences, 6(5): 67-71.

Yusni, M. A., 2008. Perbedaan pengaruh pemberian fraksi etanolik Bawang Dayak (Eleutherine palmifolia (L.) Merr.) dengan 5-Fluorouracil terhadap penghambatan pertumbuhan galur sel karsinoma kolon HT29 dan ekspresi p53 mutan, Tugas Akhir, Surakarta, Fakultas Kedokteran, Universitas Sebelas Maret/ RSUD Dr. Moewardi Surakarta. 
